\title{
THE EFFECT OF AGING ON THE DEMOGRAPHIC, INJURY AND HEALING PATTERNS OF BURN PATIENTS
}

\author{
Yigit Demir Yasemin, ${ }^{1}$ Yigit Ebral ${ }^{2}$ \\ ${ }^{1}$ Gazi Yasargil Training and Research Hospital Department of General Surgery, Diyarbakır, Turkey \\ ${ }^{2}$ Gazi Yasargil Training and Research Hospital Department of pediatrics, Diyarbakır, Turkey
}

Primljen/Received 13. 09. 2021. god.

Abstract: Introduction: This study aims to investigate the effect of increasing age on the demographic, injury, and healing patterns of burn patients.

Material and Methods: Patients who were followed up for burns in the Diyarbakır Gazi Yaşargil Training and Research Hospital Burn Centre were examined.

Results: In this study, the data of the age groups of 1415 patients with burn injuries were examined. In all groups, the most frequent cause of burns was scalding. The right and left lower extremities were the areas most affected by burns in all age groups. When we examined the patients, $74.1 \%$ of them had 2 nd-degree burns. After the age of 25, the rate of 3rd degree burns increased in parallel with age. The rate of patients with $(+)$ wound culture results in all age groups was highest in the 1-month to 4-years-old groups and after 45 years of age. APACHE scores of our patients were significantly higher for patients especially for those over the age of 65 . The rate increased in patients over 65 years of age.

Conclusion: We observed that the treatment of burns became more severe with increases in age, and mortality and morbidity rates increased.

Keywords: Burns, aging, morbidity, mortality.

\section{INTRODUCTION}

Burns are the fourth most common traumatic event globally after traffic accidents, falls, and violence between individuals; (1) burn injuries can lead to decreased quality of life, increased disability, and death.(2). According to the World Health Organization (WHO), more than 300000 people die worldwide from burn injuries each year, with the highest number of deaths occurring in Southeast Asia and the Middle East (3).
Prihvaćen/Accepted 07. 11. 2021. god.

Decreased immune response, serum albumin level, collagen production, pressure, tactile sensations, and tissue elasticity can negatively affect burn wound healing (4). Natural age progression significantly impairs wound healing, and increasing age makes burn patients more prone to infections and associated complications and worsens their clinical outcomes. Due to the physiology of aging, the dermis thickness of the skin decreases, which leads to a decrease in protection against microorganisms. Age is a crucial factor affecting the results of burns and post-burns (5).

This study aims to evaluate the patients treated in our burn center between 2016 and 2020 and to investigate the effect of increasing age on the demographic, injury, and healing patterns of burn patients.

\section{MATERIAL AND METHODS}

Between January 2016 and January 2020, patients who were followed up for burns in the Diyarbakır Gazi Yaşargil Training and Research Hospital Burn Centre, the only burn center in the southeastern Anatolia region of Turkey, were examined. This study was carried out in accordance with the principles of the 2008 Declaration of Helsinki. Medical records, causes of injury and related factors, pre-hospital and hospital treatment, demographic data (age, gender, location, application date, and discharge date), injury-related data (burn status, cause of burn injuries, total body surface area (TBSA) and degree of burn), major complications, and treatment outcomes (recovery, discontinuation, or death) were obtained from the hospital's electronic medical record system.

\section{Statistical analysis}

The data were collected and entered into Microsoft Excel 2007 (Microsoft Corp., Redmond, WA, 
USA). An analysis of variance and Fisher's least significant difference post hoc test between different groups were performed using IBM SPSS Statistics. The mean \pm standard deviation or median (interquartile range) was used to explain the distribution of the variables, and a Mann-Whitney $U$ test was performed to compare two or more groups of categorical variables (age, gender, burn type, and outcome). A multivariate logistic regression analysis was used to screen for risk factors in burn patients, and a chi-squared test was used for pair and multiple group comparisons. The statistical significance was set as $p<0.05$.

\section{RESULTS}

During the study period, 1415 patients were admitted to the hospital due to burn injuries. Of them, $798(56.4 \%)$ were male, and 617 (43.6\%) were female; $705(49.8 \%)$ patients were admitted from the emergency department and $710(50.2 \%)$ patients from the outpatient clinic.

Patient ages were as follows: $10.7 \%$ of the patients were 1 month to 1 year old, $42.5 \%$ were 1 to 4 years old, $12.5 \%$ were 5 to 9 years old, $5.0 \%$ were 10 to14 years old, $8.9 \%$ were 14 to 24 years old, $7.7 \%$ were 25 to 34 years old, $4.8 \%$ were 35 to 44 years old age, $5.5 \%$ were 45 to 64 years old, and $2 \%$ of them were 65 and older.

More applicants were from rural areas than from urban areas in the 1-month to1-year-old, 25- to 34-year-old, and 35- to 44-year-old age groups. Of all the patients, $28.4 \%$ applied visited the hospital more than 1- day after the burn trauma occurred; the 1 -month to 1-year-old and 65 and older age groups were the patient age groups with the highest late admission percentages $(3.70 \%$ and $0.80 \%$, respectively) (Figure 1). There was no statistically significant difference between age groups and late presentation (p: 0.764 ).

In all groups, the most frequent cause of burns was scalding. After 1 year of age, the frequency of scalding decreased as age increased. Flame burns showed a regular increase in parallel with an increase in age. Frostbite was seen in patients between the ages of 15 to 45 years old, while chemical burns increased after

Table 1. The cause of burn injury by age group

\begin{tabular}{|c|c|c|c|c|c|c|c|}
\hline Age groups & & Flame & Frosbite & Chemical & Scalding & Electrical & Hot object contact \\
\hline $1-11$ months & In-group $\%$ & $1.3 \%$ & $0.0 \%$ & $0.7 \%$ & $89.3 \%$ & $0.0 \%$ & $7.9 \%$ \\
\hline $1-4$ ages & In-group $\%$ & $2.5 \%$ & $0.0 \%$ & $0.8 \%$ & $89.9 \%$ & $0.3 \%$ & $6.5 \%$ \\
\hline $5-9$ ages & In-group $\%$ & $7.9 \%$ & $0.0 \%$ & $0.6 \%$ & $79.1 \%$ & $1.7 \%$ & $10.8 \%$ \\
\hline $10-14$ ages & In-group $\%$ & $18.3 \%$ & $0.0 \%$ & $0.0 \%$ & $67.6 \%$ & $2.8 \%$ & $5.1 \%$ \\
\hline $15-24$ ages & In-group $\%$ & $24.6 \%$ & $2.4 \%$ & $3.2 \%$ & $50.9 \%$ & $11.9 \%$ & $5.4 \%$ \\
\hline $25-34$ ages & In-group $\%$ & $21.1 \%$ & $0.9 \%$ & $3.7 \%$ & $53.2 \%$ & $11.0 \%$ & $5.4 \%$ \\
\hline $35-44$ ages & In-group $\%$ & $14.7 \%$ & $1.5 \%$ & $2.9 \%$ & $58.8 \%$ & $17.6 \%$ & $2.9 \%$ \\
\hline $45-64$ ages & In-group $\%$ & $20.5 \%$ & $0.0 \%$ & $5.1 \%$ & $55.1 \%$ & $7.7 \%$ & $5.1 \%$ \\
\hline+65 ages & In-group $\%$ & $24.2 \%$ & $0.0 \%$ & $3.0 \%$ & $51.5 \%$ & $3.0 \%$ & $4.1 \%$ \\
\hline Total & & $9.4 \%$ & $0.4 \%$ & $1.6 \%$ & $76.2 \%$ & $3.7 \%$ & $7.2 \%$ \\
\hline
\end{tabular}

Table 2. The most frequently injured body region in the burn trauma by age group

\begin{tabular}{|c|c|c|c|c|c|c|c|c|c|}
\hline Age groups & head neck & $\begin{array}{c}\text { right } \\
\text { upper } \\
\text { extremity }\end{array}$ & $\begin{array}{c}\text { left upper } \\
\text { extremity }\end{array}$ & $\begin{array}{c}\text { front of } \\
\text { chest and } \\
\text { abdomen }\end{array}$ & $\begin{array}{c}\text { Chest } \\
\text { posterior } \\
\text { +back }\end{array}$ & perineum & $\begin{array}{c}\text { right } \\
\text { lower } \\
\text { extremity }\end{array}$ & $\begin{array}{c}\text { left lower } \\
\text { extremity }\end{array}$ \\
\hline 1-11 months & $\%$ within age group & $15.1 \%$ & $30.3 \%$ & $45.4 \%$ & $23.7 \%$ & $5.9 \%$ & $2.6 \%$ & $42.8 \%$ & $42.1 \%$ \\
\hline 1-4 ages & $\%$ within age group & $18.8 \%$ & $30.8 \%$ & $28.8 \%$ & $30.1 \%$ & $10.0 \%$ & $5.2 \%$ & $43.4 \%$ & $42.1 \%$ \\
\hline 5-9 ages & $\%$ within age group & $22.7 \%$ & $19.3 \%$ & $24.9 \%$ & $28.4 \%$ & $5.1 \%$ & $7.9 \%$ & $50.0 \%$ & $41.8 \%$ \\
\hline $10-14$ ages & $\%$ within age group & $31.0 \%$ & $31.0 \%$ & $28.2 \%$ & $32.4 \%$ & $8.5 \%$ & $9.9 \%$ & $43.7 \%$ & $43.7 \%$ \\
\hline 15-24 ages & $\%$ within age group & $26.4 \%$ & $36.5 \%$ & $32.5 \%$ & $28.8 \%$ & $5.6 \%$ & $8.8 \%$ & $44.0 \%$ & $42.4 \%$ \\
\hline $25-34$ ages & $\%$ within age group & $30.3 \%$ & $45.9 \%$ & $43.1 \%$ & $24.8 \%$ & $2.8 \%$ & $3.7 \%$ & $34.9 \%$ & $25.7 \%$ \\
\hline $35-44$ ages & $\%$ within age group & $26.5 \%$ & $57.4 \%$ & $33.8 \%$ & $27.9 \%$ & $10.3 \%$ & $1.5 \%$ & $25.0 \%$ & $32.4 \%$ \\
\hline $45-64$ ages & $\%$ within age group & $21.8 \%$ & $32.1 \%$ & $48.7 \%$ & $20.5 \%$ & $5.1 \%$ & $0.0 \%$ & $38.5 \%$ & $38.5 \%$ \\
\hline+65 ages & $\%$ within age group & $12.1 \%$ & $18.2 \%$ & $27.3 \%$ & $18.2 \%$ & $9.1 \%$ & $9.1 \%$ & $51.5 \%$ & $57.6 \%$ \\
\hline total & $\%$ within age group & $21.4 \%$ & $32.0 \%$ & $32.8 \%$ & $27.9 \%$ & $7.6 \%$ & $5.3 \%$ & $42.6 \%$ & $40.6 \%$ \\
\hline
\end{tabular}




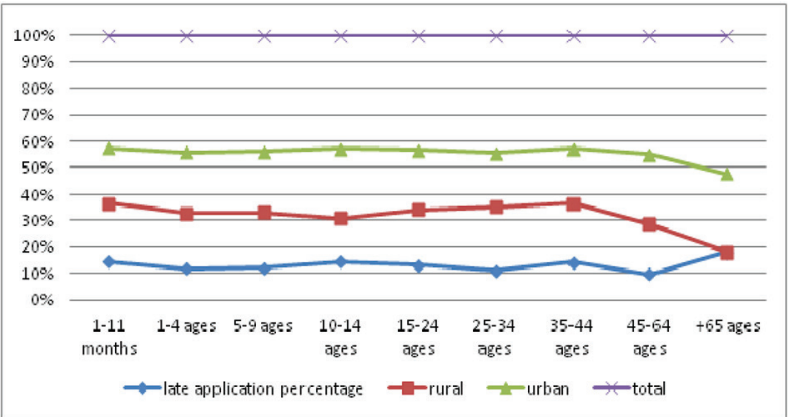

Figure 1. Demographic distribution of patients by age groups

the age of 15 and peaked between the ages of 45 to 65 . Electrical burns were most common between the ages of 35-44. Hot object contact burns were most common in the 1-month to 1-year-old, 1- to 4-year-old, and 5- to 9-year-old age groups (Table 1).

A regular increase was observed in head and neck burns after one year of age that peaked between the ages of 25 to 34, after which it steadily decreased. However, it was not statistically significant (p: 0.12). The right and left lower extremities were the regions most affected by burns in all age groups, but this find-

Table 3. Average percentage of burns by age groups

\begin{tabular}{|c|c|c|}
\hline Age groups & Average percentage of burns & STD Deviation \\
\hline 1-11 months & 8.42 & 5.169 \\
\hline 1-4 ages & 9.52 & 6.658 \\
\hline 5-9 ages & 8.94 & 5.747 \\
\hline 10-14 ages & 9.41 & 7.543 \\
\hline 15-24 ages & 9.71 & 7.965 \\
\hline $25-34$ ages & 8.41 & 6.419 \\
\hline $35-44$ ages & 9.88 & 8.334 \\
\hline $45-64$ ages & 9.67 & 8.046 \\
\hline+65 ages & 7.24 & 5.568 \\
\hline Total & 9.23 & 6.722 \\
\hline
\end{tabular}

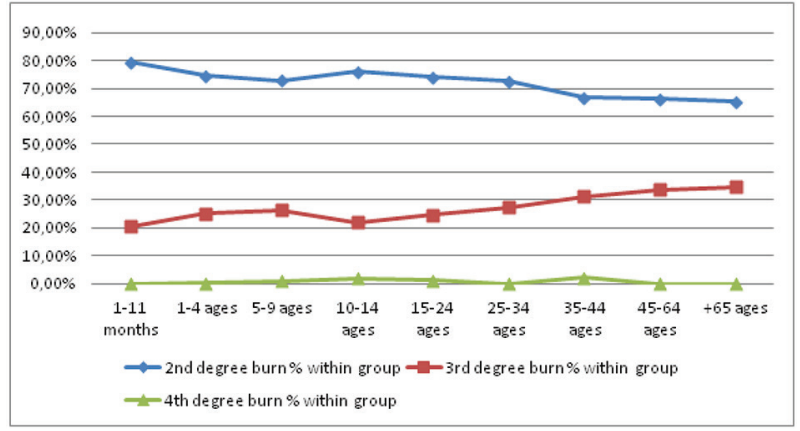

Figure 2. Distribution of burn degrees by age groups

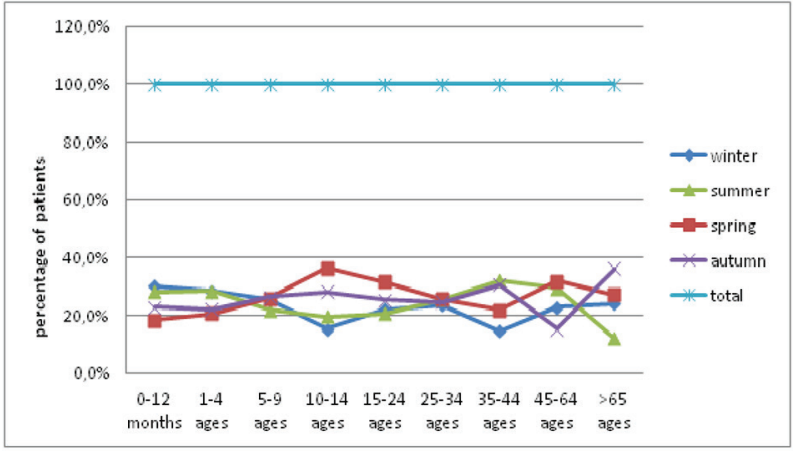

Figiue 3. Seasonal distribution of hospitalization

ing was not statistically significant (p: 0.24) (Table 2).

Right upper extremity burns were mostly observed in the 25 to 44 age group, while left upper extremity burns were mostly observed between the ages of 45 to 64 . Perineal burns were most common between the ages of 10-14 and 65 and older, but the results were not statistically significant (p: 0.45). The mean percentage of the TBSA was $9.23 \pm 6.72$ and peaked in the 35 - to 44-year-old-age group (Table 3).

When we examined the patients, $74.1 \%$ of them had second-degree burns. There was no statistical difference between age groups and burn degrees ( $\mathrm{p}$ : $0.10)$. After the age of 25 , the rate of third-degree burns increased in parallel with age (Figure 2). Of the patients, $24.1 \%$ were hospitalized in winter, $24.1 \%$ in

Table 4. Percentage of distribution of wound culture results by age groups

\begin{tabular}{|c|c|c|c|c|c|c|c|c|c|}
\hline & $\begin{array}{c}1-11 \\
\text { months }\end{array}$ & $\begin{array}{c}1-4 \\
\text { ages }\end{array}$ & $\begin{array}{c}5-9 \\
\text { ages }\end{array}$ & $\begin{array}{c}10-14 \\
\text { ages }\end{array}$ & $\begin{array}{c}15-24 \\
\text { ages }\end{array}$ & $\begin{array}{l}25-34 \\
\text { ages }\end{array}$ & $\begin{array}{c}35-44 \\
\text { ages }\end{array}$ & $\begin{array}{l}45-64 \\
\text { ages }\end{array}$ & +65 ages \\
\hline $\begin{array}{c}\text { Staphylococcus culture }(+) \\
\text { in its age group }\end{array}$ & $14.5 \%$ & $19.3 \%$ & $13.56 \%$ & $6.05 \%$ & $17.4 \%$ & $17.43 \%$ & $13.2 \%$ & $15.4 \%$ & $21.2 \%$ \\
\hline $\begin{array}{l}\text { Streptococcus culture }(+) \\
\text { in its age group }\end{array}$ & $0.66 \%$ & $0.67 \%$ & $1.13 \%$ & & $1.58 \%$ & $0.92 \%$ & $1.47 \%$ & & \\
\hline $\begin{array}{l}\text { Escherichia coli culture } \\
(+) \text { in its age group }\end{array}$ & $3.9 \%$ & $3.17 \%$ & $1.13 \%$ & $1.40 \%$ & & & $4.41 \%$ & $2.56 \%$ & \\
\hline $\begin{array}{c}\text { Pseudomonas culture }(+) \\
\text { in its age group }\end{array}$ & $1.4 \%$ & $2.0 \%$ & $3.39 \%$ & & $3.96 \%$ & $4.59 \%$ & $2.94 \%$ & $7.69 \%$ & $3.03 \%$ \\
\hline $\begin{array}{l}\text { Culture }(+) \text { within } \\
\text { its age group }\end{array}$ & $24.3 \%$ & $30.9 \%$ & $22.0 \%$ & $19.7 \%$ & $29.4 \%$ & $27.5 \%$ & $26.5 \%$ & $29.5 \%$ & $31.3 \%$ \\
\hline
\end{tabular}




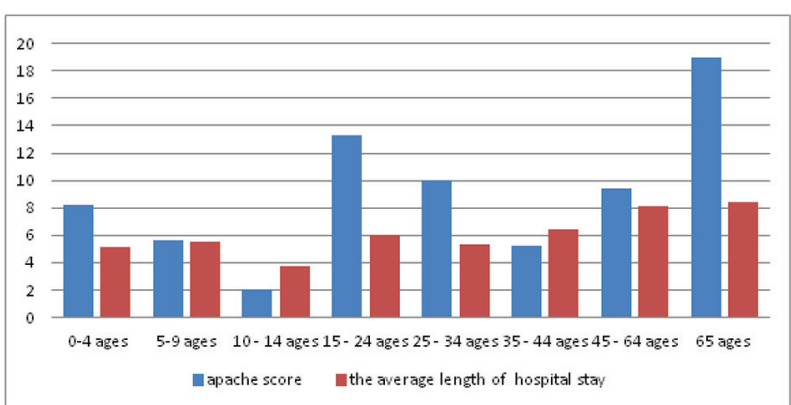

Figure 4. Distribution of apache score and lenght of hospital stay according to age groups

summer, $25.7 \%$ in spring, and $26.1 \%$ in autumn (Figure 3). There was no statistically significant difference between seasonal burns and age groups (p: 0.11).

The rate of patients with $(+)$ wound culture results in all age groups was highest in the 1-month to 4 -years-old groups and after 45 years of age. The most common bacteria were staphylococcus from gram $(+)$, pseudomonas, and E. coli from gram (-). Staphylococcus, which was found to reproduce most in the 1-month to 4-years-old groups as a result of wound culture $(+)$, decreased gradually after 5 years of age. It increased again at the age of 45 and above. The number of Pseudomonas culture ( + ) cultivars increased in parallel with increasing age (Table 4).

When we look at the Acute Physiology and Chronic Health Evaluation (APACHE) scores of our patients hospitalized in the intensive care unit, they were significantly higher for patients aged 15 to 25 and especially for those over the age of 65 . The mean length of hospital stay increased systematically after 14 years of age, but it was not statistically significant (p: 0.33) (Figure 4). Our average length of stay is $5.5 \pm 5.19$ days. Skin grafts were performed on 561 (39.64\%) patients, and $854(60.36 \%)$ patients were treated with silver nitrate dressings or nitrofurazone dressing after escharotomy.

A total of 22 (1.55\%) of our patients died: 13 were under the age of 14, 6 were between the ages of 15 to 64 , and 3 were 65 years or older.

\section{DISCUSSION}

The aging process occurs at the cellular and immunological levels, and we believe it to be a result of the accumulation of cellular damage over time (6). With increasing age, skin functions are affected by internal and external factors and deteriorate due to morphological and structural changes (7). Although wound healing does not deteriorate spontaneously with age, age-related changes are evident in all stages of wound repair (8). In patients 65 years and older, the interruption of any step in any wound healing phase has been reported to cause a 20 to $60 \%$ delay in healing (4). In our study, it was observed that the duration of patient hospitalizations increased consistently with increases in age since the healing of wounds was prolonged in individuals over the age of 44 years.

Most of the individuals living in the rural areas of the southeastern Anatolia region of Turkey live in low socioeconomic circumstances, similar to other rural families. In the spring and autumn seasons, one of their primary economic activities is producing dairy products. During the preparation process, milk is boiled in copper vessels and then allowed to cool to a sufficient degree to add a particular fermentation culture and is consequently stored in the optimum warm outdoor conditions for fermentation. Since it is produced in large containers, it creates a potentially dangerous situation for child burns during the production period. Children unintentionally bump into these copper pots and spill their contents on themselves or accidentally fall into them. Both cases cause scalding. Families with multiple children and environmental factors increase the risk of childhood injury (9). In our study, $53.2 \%$ of the patients with the most burn trauma were in the first four age groups, and their burn injuries predominately occurred in the spring and autumn seasons. The patients aged 65 years and older were mostly seen in the winter season. Burn trauma was most common in spring and autumn in all patients. Chien et al. (10) stated that the most common season of burns was spring, but Nilgün et al. (11) asserted that the most common season was summer.

The epidermis and dermis become thinner with age along with decreased sensation and sometimes decreased blood flow which makes the skin more susceptible to 3rd and 4th-degree burns, therefore increasing the need for surgery in burn patients (12). Consequently, our skin grafting rate increased in parallel with age, starting from the age of 25 .

According to the studies of Ho and Rao et al., burns in all age groups most commonly affect the extremities, followed by the trunk, head, and neck (13, 14). Our study findings are consistent with their results.

Comorbid diseases that increase with age become more susceptible to infection due to aging and the weakening of immunity. Therefore, special care should be taken to prevent and treat infection in elderly burn patients $(15,16)$. In our study, higher wound culture $(+)$ rates were found in the 1 - to 5 -year-olds and 65 and older age groups. We attributed this to the lack of development of the immune system in children and the suppression of the immune system in patients aged 65 and older.

In the literature, mortality rates among burn patients differ between studies but certainly increase with age (8). In our study, the mortality rate was $1.55 \%$ in all patients, while $9.09 \%$ in the 65 and older age group. 
We attribute this to the increase of comorbid diseases with increasing age and the high APACHE scores in the intensive care unit.

\section{CONCLUSION}

Intrinsic factors that change with age affect the treatment of burns. In our study, we observed that the treatment of burns became more severe with increases in age, as a result of which the hospitalization period of the patient was prolonged and mortality and morbidity increased.

\section{Acknowledgment}

None.

Conflict of Interests: The authors declare that there are no conflicts of interest related to this article.

Funding: None

\section{Licensing}

This work is licensed under a Creative Commons Attribution 4.0 International (CC BY 4.0) License.

\title{
Sažetak
}

\section{UTICAJ STARENJA NA DEMOGRAFIJU, POVREDE I OBRASCE LEČENJA BOLESNIKA SA OPEKOTINAMA}

\author{
Yigit Demir Yasemin, ${ }^{1}$ Yigit Ebral ${ }^{2}$ \\ ${ }^{1}$ Gazi Yasargil Training and Research Hospital Department of General Surgery, Diyarbakır, Turkey \\ ${ }^{2}$ Gazi Yasargil Training and Research Hospital Department of pediatrics, Diyarbakır, Turkey
}

Uvod: Cilj ove studije je da istraži uticaj godina na demografiju, povrede i obrasce lečenja pacijenata sa opekotinama.

Materijal i metode: Pacijenti koji su praćeni zbog opekotina u Centru za opekotine Diiarbakır Gazi Iasargil su pregledani.

Rezultati: U ovoj studiji ispitani su podaci starosnih grupa od 1415 pacijenata sa opekotinama. U svim grupama najčešći uzrok povreda bile su opekotine. Desni i levi donji ekstremiteti su bila područja koja su najviše zahvaćena opekotinama u svim starosnim grupama. Nakon što smo pregladali pacijente, ustanovili smo da $24.1 \%$ ima opekotine drugog stepena. Posle

\section{REFERENCES}

1. Peck MD. Epidemiology of burns throughout the World. Part II: intentional burns in adults. Burns. 2012; 38(5): 630-7. doi: 10.1016/j.burns.2011.12.028.

2. Arshi S, Sadeghi-Bazargani H, Mohammadi R, Ekman R, Hudson D, Djafarzadeh H, et al. Prevention oriented epidemiologic study of accidental burns in rural areas of Ardabil, Iran. Burns. 2006; 32(3): 366-71. doi: 10.1016/j. burns.2005.10.026

3. Mehta K, Arega H, Smith NL, Li K, Gause E, Lee J, et al. Gender-based disparities in burn injuries, care and outcomes: A World Health Organization (WHO) Global Burn Registry cohort study. Am J Surg. 2021 Jul 24: S0002-9610(21)00421-9. doi: 10.1016/j.amjsurg.2021.07.041.

4. Elloso M, Kambli A, Aijaz A, van de Kamp A, Jeschke MG. Burns in the elderly: potential role of stem cells. Int J Mol Sci. 2020; 21(13): 4604. doi: 10.3390/ijms21134604.

5. Abdullahi A, Knuth CM, Auger C, Sivayoganathan T, Parousis A, Jeschke MG. Adipose browning response to
25. godine, stopa opekotina 3. stepena se povećavala paralelno sa godinama.

Stopa pacijenata sa $(+)$ rezultatima brisa rane $u$ svim starosnim grupama bila je najveća u grupama od 1 meseca do 4 godine i nakon 45 godina.

APACHE rezultati naših pacijenata bili su značajno viši za pacijente, posebno za one starije od 65 godina. Stopa se povećala kod pacijenata starijih od 65 godina.

Zaključak: Primetili smo da je lečenje opekotina postalo teže sa porastom godina, uz porast stopa mortaliteta i morbiditeta.

Ključne reči: opekotine, starenje, morbiditet, mortalitet.

burn trauma is impaired with aging. JCI Insight. 2021; 6(16): e143451. doi: 10.1172/jci.insight.143451.

6. Mahbub S, Brubaker AL, Kovacs EJ. Aging of the innate immune system: an update. Curr Immunol Rev. 2011; 7(1): 104-15. doi: 10.2174/157339511794474181.

7. Boismal F, Serror K, Dobos G, Zuelgaray E, Bensussan A, Michel L. Vieillissement cutané - Physiopathologie et thérapies innovantes [Skin aging: Pathophysiology and innovative therapies]. Med Sci (Paris). 2020; 36(12): 1163-72. Doi:10.1051/medsci/2020232.

8. Sgonc R, Gruber J. Age-related aspects of cutaneous wound healing: a mini-review. Gerontology. 2013; 59(2): 15964. doi: 10.1159/000342344.

9. Sakallioglu AE, Basaran O, Tarim A, Turk E, Kut A, Haberal M. Burns in Turkish children and adolescents: nine years of experience. Burns. 2007; 33(1): 46-51. doi: 10.1016/j. burns.2006.05.003.

10. Chien WC, Pai L, Lin CC, Chen HC. Epidemiology of hospitalized burns patients in Taiwan. Burns. 2003; 29(6): 5828. doi: 10.1016/s0305-4179(03)00133-5. 
11. Aksoy N, Arli S, Yigit O. A retrospective analysis of the burn injury patients records in the emergency department, an epidemiologic study. Emerg (Tehran). 2014; 2(3): 115-20.

12. Jeschke MG, Peck MD. Burn care of the elderly. J Burn Care Res. 2017; 38(3): 625-8. doi: 10.1097/ BCR.0000000000000535.

13. Ho WS, Ying SY, Chan HH. A study of burn injuries in the elderly in a regional burn centre. Burns. 2001; 27(4): 382-5. doi: 10.1016/s0305-4179(00)00146-7.
14. Rao K, Ali SN, Moiemen NS. Aetiology and outcome of burns in the elderly. Burns. 2006; 32(7): 802-5. doi: 10.1016/j.burns.2006.03.024.

15. Savetamal A. Infection in elderly burn patients: What do we know? Surg Infect (Larchmt). 2021; 22(1): 65-8. doi: 10.1089/sur.2020.322.

16. Grutzner PA. Alterstraumatologie (Geriatric trauma). Der Chirurg. 2019; 90(10): 781.doi:10.1007/s00104-01901018-4.

\section{Correspondence to/Autor za korespondenciju} Ebral Yiğit MD.

Address: Gazi Yasargil Training and Research Hospital Department of General Surgery, Diyarbakır, Turkey Turkey. Zipcode: 21090.

Phone: +905334889334

Fax:+90 4122580060

Email: ebralyigit@gmail.com

ORCID: 0000-0001-8766-0754

How to cite this article. Yigit DY, Yigit E. The effect of aging on demographic, injury and healing patterns of burn patients. Sanamed.2021;16(3): 209-214 